\title{
Organizational culture as a risk factor in projects
}

\author{
Katarzyna Piwowar-Sulej \\ Wroclaw University of Economics and Business
}

\section{Introduction}

According to Levine, project management was the most recognizable trend of the $90 \mathrm{~s}^{1}$. It seems that this situation has persisted until today, as evidenced by the number of associations for project management enthusiasts, publications, trainings, postgraduate studies or conferences addressing the project related problems. Currently, projects play an important role even in these industries where repetitive activities are traditionally the basis of functioning (e.g. trade or production). Despite the ongoing development of the project management research area, many projects continue to fail. The research conducted by Standish Group International shows that although the percentage of unsuccessful projects declines year by year, it still remains at the level either equal or close to $60 \%{ }^{2}$. In this case, failure is identified with such deviations as:

- delays in the project;

- failure to implementation a certain scope of the project;

- higher project costs.

Project definitions draw attention to the fact that a project represents a temporary social system (work system), constituted by a team in order to implement a specific task within a given timeframe and budget constraints. The process-oriented nature of the project, task uniqueness, complexity and complication or the need to apply specific methods are also often highlighted ${ }^{3}$. Each project, in its essence, including

1 H.A. Levine, Practical Project Management. Tips, Tactics, and Tools, John Wiley \& Sons, New York 2002, p. 19.

2 Standish Group, Chaos Report 2015, The Standish Group International, Inc., 2015, p. 1, https://www.standishgroup.com/sample_research_files/CHAOSReport2015-Final.pdf (accessed: 25.03.2020).

3 For more see: K. Piwowar-Sulej, Zarzqdzanie ludźmi w organizacjach zorientowanych na projekty, Difin, Warszawa 2016, pp. 40-43. 
such features as complexity, uniqueness and complication is subject to risk, defined as the "cumulative effect of the probability of uncertain occurrences that may positively or negatively affect completion of a project" 4 . Although this definition carries a positive message, risk is more often identified with the possibility that something will go wrong 5 . Referring to the main goals of each project, as well as the negative consequences, it can be stated that this risk is connected with the possibility of unexpected circumstances causing the aforementioned deviations.

All the activities related to risk, and specifically to higher security of business operations are referred to as the so-called risk management. It is also present in projects. A detailed analysis of the nature and extent of the potential risk allows preventive action to be taken in due time or allows for the impact of risk to be minimized. There is also a risk of not taking specific actions. The goal of risk management is - if not guaranteed (as it is difficult) - to bring the project closer to success. This success can be defined through the prism of achieving the abovementioned three project parameters, but also taking into account such elements as the level of customer or project team satisfaction ${ }^{6}$.

A project and a project team represent the immanently correlated concepts. As indicated earlier, a project is a social system. People, the members of the defined team, should use their competences and motivation effectively in order to achieve the adopted project results. Meanwhile, people, as the most unpredictable so-called "soft resource" of each project, remain the source of risk. It is them who bring their norms, values, routine behaviours to work, thus creating an organizational culture. This culture acts like "glue which bonds the organization together through the shared patterns and meaning"7. However, it can have either a positive or a negative impact on the achieved results.

The purpose of this article is to present organizational culture as a project risk factor. In writing this article, references were made to the subject literature presentation of risk areas in projects. It was highlighted in this article that since every organization has its own culture, a single project, as a micro-organization also has its own culture and influence exists between the two. Finally, the empirical research results on the impact of culture on project success are presented. The article

4 C. Pritchard, Zarzq̨dzanie ryzykiem w projektach. Teoria i praktyka, WIG Press, Warszawa 2001, p. 7.

5 J. Bralczyk (ed.), Stownik: 100 tysięcy potrzebnych stów, Wydawnictwo Naukowe PWN, Warszawa 2005, p. 735.

6 For more see: G. Sudhakar, Understanding the Meaning of Project Success, "Binus Business Review" 2016, vol. 7, pp. 163-169.

7 C. Siehl, J. Martin, The role of symbolic management: How can managers effectively transit organizational culture?, [in:] J. Hunt et al. (eds), Leaders and managers. International perspectives on managerial behavior and leadership, Elmsford, Pergamon, New York 1984, p. 22. 
is of a theoretical and pragmatic nature. The conducted literature review aimed at answering the following question: "Which features and types of organizational culture have a positive impact on project success?". The literature review resulted in certain implications for the practitioners and theorists of management.

\section{Organizational culture at the background of other project risk factors - literature approach}

The identification of areas, sources, components, risk factors or causes of failures in projects is the basis of risk management. Some factors are internal to the project, others are intra-organizational, whereas still others are a consequence of the processes occurring in an organization's environment (see Table 1).

Table 1. Areas and examples of the specific sources of project risk

\begin{tabular}{|c|c|c|}
\hline \multicolumn{3}{|c|}{ Areas of project risk } \\
\hline Environment risk & Internal project risk & Intra-organizational risk \\
\hline $\begin{array}{l}\text { External sources } \\
\text { of project risk }\end{array}$ & $\begin{array}{l}\text { Internal sources } \\
\text { of project risk }\end{array}$ & $\begin{array}{c}\text { Organizational sources } \\
\text { of project risk }\end{array}$ \\
\hline $\begin{array}{l}\text { - Economic situation } \\
\text { - Legal environment } \\
\text { - Force majeure } \\
\text { - External project } \\
\text { shareholders }\end{array}$ & $\begin{array}{l}\text { - Project funding } \\
\text { - Form of processes in a project } \\
\text { - Features of project } \\
\text { management entities (including } \\
\text { the team adopted management } \\
\text { method) } \\
\text { - Attitude of the project sponsor } \\
\text { - Beneficiaries' behavior } \\
\text { - Features of project executors } \\
\text { (competences, behavior } \\
\text { of project team members) }\end{array}$ & $\begin{array}{l}\text { - Incorrect training policy } \\
\text { - Acceptance for project } \\
\text { implementation in isolation } \\
\text { from the strategy } \\
\text { - Inability to create a truly } \\
\text { interdisciplinary team } \\
\text { - Lack of commitment from the } \\
\text { organization management } \\
\text { - Reluctance to change } \\
\text { - Absence of adequate resources }\end{array}$ \\
\hline
\end{tabular}

Source: author's compilation based on J. Bizon-Górecka, W poszukiwaniu modelu zarządzania organizacja przez projekty, "Przegląd Organizacji” 2009, vol. 2, p. 25; R. Jones, Zarzq̨dzanie projektami. Sztuka przetrwania, MT Biznes, Warszawa 2007, pp. 23-25; T.L. Young, Skuteczne zarządzanie projektami, Wydawnictwo Helion, Gliwice 2006, pp. 16-17.

Organizational culture is, beyond doubt, one of the project risk factors. According to such authors as Kendra and Taplin, success in project management depends, among others, on the management practices representing organizational culture ${ }^{8}$. However, as the table above shows, such components as the adopted method of project management and the behaviour of project team members are critical to project success. A hypothesis can be put forward that these factors represent the elements

8 K. Kendra, L.J. Taplin, Project success: A cultural framework, "Project Management Journal” 2004, vol. 35(1), pp. 30-45. 
of the so-called internal project culture. Each project is a micro-organization with its own values and behaviours. The examples of cultural artifacts in a project team are presented in Table 2.

Table 2. Examples of cultural artifacts in a project team

\begin{tabular}{|c|c|c|}
\hline \multicolumn{3}{|c|}{ Groups of cultural artifacts in a project team } \\
\hline Linguistic & Behavioural & Physical \\
\hline $\begin{array}{l}\text { - Specific project } \\
\text { terminology } \\
\text { - The way team members } \\
\text { address each other } \\
\text { - Taboos }\end{array}$ & $\begin{array}{l}\text { - Organization of meetings } \\
\text { - Communication rules (channels) } \\
\text { - Cooperation rules of team members } \\
\text { with the project manager } \\
\text { - Keeping the records } \\
\text { - Work control rules } \\
\text { - Rewarding team members }\end{array}$ & $\begin{array}{l}\text { - Material conditions } \\
\text { of teamwork } \\
\text { - Outfit of project team } \\
\text { members }\end{array}$ \\
\hline
\end{tabular}

Source: author's compilation using P. Wachowiak et al., Kierowanie zespotem projektowym, Difin, Warszawa 2004, p. 83.

Finally, the organizational culture of the entire enterprise has to be taken into account, covering such factors as the training policy or the attitude towards changes which are listed in the last column of Table 1. Organizational culture like the subconscious affects aspirations, attitudes and employee behaviour. Feedback is present between the organizational culture of subsequent projects and the culture of the entire organization. The organizational culture of an enterprise defines the approach to change and risk (whereas each project, as indicated in the introduction, is burdened with risk by definition). Organizational culture also shows the value of projects and project work. In turn, norms and rules of cooperation in project teams or a specific language can be "transferred" to the culture of the entire organization. The culture connecting people in an organization is very closely related to the results achieved by this organization. It may fail to facilitate effective actions, or even counteract them through developing or consolidating specific attitudes and employees' behaviour.

\section{Features of organizational culture having a positive impact on project results}

Kerzner is of the opinion that project management is a culture, rather than politics or procedures 9 . Therefore, the concept of the so-called project (pro-project) culture is used. The literature on project management presents the characteristics

$9 \quad$ H. Kerzner, Applied Project Management. Best Practices on Implementation, John Wiley \& Sons, New York 2000, p. 212. 
of the culture under study, which covers the strictly defined features supporting the implementation of changes in an organization or in teamwork. At this point it is, however, worth emphasizing that in English-language publications addressing the problem of project management such terms as "project culture", "project management culture", "project climate" and "project environment" function interchangeably ${ }^{10}$. In Polish scientific literature, however, working environment is mostly identified with working conditions (material and non-material ones, as well as the broadly understood occupational health and safety $\left.{ }^{11}\right)$. The climate, in turn, is only an external, easily observable layer of culture and stands for the subjective feelings of employees referring to the atmosphere in the workplace ${ }^{12}$.

For example, as the research conducted by Doolen, Hacker, and van Aken shows the organizational culture promoting communication and cooperation between teams affects the satisfaction of team members and the effectiveness of team management $^{13}$. Due to the fact that projects are based on teams, the hypothesis can be formulated that the culture characterized with the indicated features will have a positive influence on the results of projects.

Many authors have conducted a more detailed research on organizational culture, connecting it directly with the problem of project management. For example, Belassi, Kondra, and Tukel showed a significant relationship between culture, positive work environment with strong leadership and the success of projects focused on new product development ${ }^{14}$.

Morrison, Brown, and Smit provide evidence that organizational culture has a significant relationship with the effectiveness of project management. In particular, attention should be paid to the relatively strong correlation with the previously mentioned effectiveness of such values as respect and inter-functional integration ${ }^{15}$.

10 Y. Du Plessis, C. Hoole, An Operational "Project Management Culture" Framework (Part 1), "SA Journal of Human Resource Management" 2006, vol. 4(1), pp. 36-43.

11 See e.g. E. Janosik et al., Wpływ fizycznych czynników środowiska pracy na obciq̨żenia praca monotypowa, "Zeszyty Naukowe Małopolskiej Wyższej Szkoły Ekonomicznej w Tarnowie" 2018, vol. 38, no. 2, pp. 121-137.

12 J. Skalik, Kulturowe uwarunkowania wzrostu i rozwoju organizacji gospodarczych, [in:] B. Mikuła (ed.), Historia i perspektywy nauk o zarządzaniu, Fundacja Uniwersytetu Ekonomicznego w Krakowie, Kraków 2012, pp. 123-130.

13 T.L. Doolen, M.E. Hacker, E.M. van Aken, Impact of organizational context on work team effectiveness: a study of production team, "IEEE Transactions on Engineering Management" 2003, no. 50, pp. 285-296.

14 W. Belassi, A.Z. Kondra, O.I. Tukel, New Product Development Projects: The Effects of Organizational Culture, "Project Management Journal" 2007, vol. 38, no. 4, p. 15.

15 J.M. Morrison, C.J. Brown, E.V.D.M. Smit, The impact of organizational culture on project management in matrix organizations, "South African Journal of Business Management" 2008, 
In turn, Graham and Englund identified eight factors which have a direct impact on project success. They are as follows: strategic emphasis, upper management support, project planning support, customer/end user input, project team development, project execution support, communication and information system and organizational support ${ }^{16}$. In such an environment, teamwork and inter-functional tasks remain a norm, conflicts are identified and resolved, and perfection is the driving force ${ }^{17}$.

In addition, project culture is based on such values as: mutual trust, respect, open communication, risk and conflict tolerance of the disciplines combined with flexibility, result orientation, support and faith in making the right decisions, kindness and compliance with the principles of professional ethics ${ }^{18}$.

Some researchers address the problem of national culture impact on project outcomes. It is emphasized that national culture determines organizational culture which, in turn, affects the execution of projects. The basic concept used in these studies is the one by Hofstede ${ }^{19}$, which distinguishes such cultural dimensions as power distance, the degree of uncertainty avoidance, individualism and collectivism, long- or short-term orientation. Attention is primarily drawn to the need for education in the area of cultural differences for the success of projects executed by international teams ${ }^{20}$. The impact of these differences on the specific tasks, implemented as part of project management, such as risk management, is also analyzed. Risk is perceived and managed differently in various cultures. The feature of Polish culture, in the form of avoiding uncertainty, results in many rigorous conditions of cooperation included in the agreements with contractors ${ }^{21}$.

vol. 39, no. 4, pp. 27-36.

16 R.J. Graham, R.L. Englund, Creating an Environment for Successful Projects, Jossey-Bass, San Francisco 1997.

17 C.F. Gray, E.W. Larson, Project Management - The managerial process, Irwin McGraw-Hill, New York 2003.

18 T.L. Young, Skuteczne zarzadzanie..., pp. 40-41; J.K. Pinto, D.P. Slevin, Critical factors in successful project implementation, "IEEE Transactions on Engineering Management" 1987, no. 34, pp. 22-27; J.M. Morrison, C.J. Brown, E.V.D.M. Smit, The impact of organizational culture..., p. 32; Y. Du Plessis, C. Hoole, An Operational "Project Management Culture" Framework..., pp. 36-43.

19 G. Hofstede, Culture and organizations, "International Studies of Management and Organization" 1981, vol. 10(4), pp. 15-41.

20 B. Shore, B.J. Cross, Exploring the role of national culture in the management of largescale international science projects, "International Journal of Project Management" 2005, vol. 23, pp. 55-64.

21 J. Liu, F. Meng, R. Fellows, An exploratory study of understanding project risk management from the perspective of national culture, "International Journal of Project Management" 2015, vol. 33, pp. 564-575. 
Kivrak and his research team showed that collectivism is conducive to knowledge sharing, however, only within a project team (not with outsiders) ${ }^{22}$. The same author also used Hall's ${ }^{23}$ typology to illustrate how national culture determines knowledge sharing in an international project. The indicated typology distinguishes high and lowcontext cultures. The messages in a low-context culture are unambiguous and reflect fairly accurately the speaker's intentions, which leaves little space for free interpretation. In the case of high-context communication the message contains ambiguity. Studies have shown that high-context content is a strong barrier in the process of tacit knowledge sharing. In addition, such cultural features as hierarchy and competition hamper knowledge sharing in international projects. Religion is not included in the study.

Returning to the organizational culture, the hypothesis can be formulated that the typology of organizational cultures by Cameron and Quinn ${ }^{24}$ is most often discussed in the studies addressing project management problems, although the output of management sciences includes numerous classifications of organizational cultures. The concept proposed by the aforementioned authors covers such cultural types as clan, market, adhocracy and hierarchy culture. For example, the research conducted in the US involving 86 project managers in 76 companies indicates a strong correlation between clan culture and high project effectiveness and the overall organization activity. It appears that this type of culture - focused on employee participation, social cohesion, shared values, commitment, high morale - guarantees the achievement of project goals, meeting client expectations within the adopted timeframe as well as team satisfaction.

The research conducted by Wiewióra and her research team also confirms that clan culture, promoting a collaborative environment in which people are encouraged to communicate will facilitate knowledge sharing, even about the mistakes made 25 . In turn, the market culture, centred around such values as competitiveness, achievements and the focus on performance measurements, will probably hamper knowledge and skills sharing in the project. However, according to the results of previous studies by the author of this article, projects are also successfully completed in the cultures with dominant "hierarchical-market" features ${ }^{26}$.

22 S. Kivrak et al., Impact of national culture on knowledge sharing in international construction projects, "Canadian Journal of Civil Engineering” 2014, vol. 41, pp. 642-649.

23 E.T. Hall, Beyond culture, Anchor Press, Garden City 1976.

24 K.S. Cameron, R.E. Quinn, Diagnosing and Changing Organisational Culture Based on Competing Values Framework, Josey Bass, San Francisco 2006.

25 A. Wiewióra et al., Uncovering the Impact of Organizational Culture Types on the Willingness to Share Knowledge between Projects, [in:] Proceedings of the Conference: Kumamoto, Japan 2012, pp. 1-16.

26 K. Piwowar-Sulej, Kultura organizacyjna i jej wpływ na działalność projektowq - studium przypadku, "Marketing i Rynek" 2014, no. 5, pp. 143-148. 
Do Carmo Silvaa, Francisco, and Gomes conducted research ${ }^{27}$ using the typology of cultures proposed by Handy ${ }^{28}$. This approach identifies four characteristic types of organizational culture: power, role, task and person-oriented culture. It is worth noting here that the task-oriented culture is directly referred to as the project-oriented one. The organizations focused on tasks recognize tasks and their completion as the most important. What matters are personal competences and the contribution to specific actions. Teams following these principles are extremely flexible and easily adapt to the situation requirements. They are formed for a specific purpose, which determines the sense of their existence. Such a team works fast in both taking actions and making decisions. Individual team members have an extensive range of freedom, but also face the responsibility for their work. The effects matter. Mutual relationships are usually quite loose, based more on the value of skills and input rather than age and formal status. The orientation on action allows the solving of problems through discussions and joint negotiations, which gives the sense of co-creating the solution. Such teams usually work well in a changing and highly competitive environment. The research undertaken by the previously mentioned authors shows that diverse cultural types are present in different organizations which conduct projects successfully. Not only the culture type but also the industry specificity is important here. In addition, projects are successfully executed when - apart from culture - other factors also affect this success (e.g. selection of the appropriate project management methodology 29 ).

\section{Conclusions}

In has been indicated in the article that wrong organizational culture may become the source of project risk. The elements of organizational culture are recognized within internal and intra-organizational risk areas in projects. The article addresses organizational culture without ignoring the importance of culture in the project itself.

Organizational culture can be developed with due awareness. The conducted literature review identifies the features to be included in organizational culture. While there is general consent that, for example, the culture based on trust has

27 M. Do Carmo Silvaa, C. Francisco, S. Gomes, Practices in project management according to Charles Handy's organizational culture typologies, "Procedia Computer Science" 2015, no. 55, pp. 678-687.

28 Ch. Handy, Understanding organizations, Oxford University Press, New York 1983.

29 K. Piwowar-Sulej, Types of Organizational Culture in the context of Project Management Methodologies, [in:] Proceedings 35th International Business Information Management Association Conference (IBIMA), 1-2 April 2020, Seville [in print]. 
a positive impact on project success, it is impossible to answer explicitly the question which type of culture (taking into account different typologies) remains the best. Although Clan culture seems to be the most appropriate, other cultural types in combination with various factors can facilitate project success as well.

Referring to the research on the types of culture in the context of project success, it should be observed that in the real world organizations are rarely characterized by one type of culture. It is believed that for its effectiveness an organization may be forced to achieve "good" results in all cultural types. The best results are achieved by the organizations in which all four cultural types listed by Cameron and Quinn are adequately balanced ${ }^{30}$.

Measuring the impact that culture may have on project outcomes is difficult. The development of organizational culture featuring the specific characteristics is influenced by many factors, both endo- and exogenous. Internal factors include, among others, the organization's vision and strategy, age or personal traits of the employees (age, gender, education). In addition, certain external factors influencing the formation of organizational culture can be identified, such as market, demographic, cultural, economic and legal determinants. Some of these factors are beyond the influence of an organization participants. Therefore, it is worth undertaking in-depth, comprehensive research on the combined and mutual influence of various factors determining project results.

\section{References}

Belassi W., Kondra A.Z., Tukel O.I., New Product Development Projects: The Effects of Organizational Culture, "Project Management Journal" 2007, vol. 38, no. 4, pp. 12-24.

Bizon-Górecka J., W poszukiwaniu modelu zarządzania organizacja przez projekty, "Przegląd Organizacji” 2009, vol. 2, pp. 21-25.

Bralczyk J. (ed.), Stownik: 100 tysięcy potrzebnych słów, Wydawnictwo Naukowe PWN, Warszawa 2005.

Cameron K.S., Quinn R.E., Diagnosing and Changing Organisational Culture Based on Competing Values Framework, Josey Bass, San Francisco 2006.

Do Carmo Silvaa M., Francisco C., Gomes S., Practices in project management according to Charles Handy's organizational culture typologies, "Procedia Computer Science" 2015, no. 55, pp. 678-687.

Doolen T.L., Hacker M.E., Aken E.M. van, Impact of organizational context on work team effectiveness: a study of production team, "IEEE Transactions on Engineering Management" 2003, no. 50, pp. 285-296.

Du Plessis Y., Hoole C., An Operational "Project Management Culture" Framework (Part 1), "SA Journal of Human Resource Management” 2006, vol. 4(1), pp. 36-43.

30 T. Yu, N. Wu, A review of study on the competing values framework, "International Journal of Business and Management" 2009, vol. 4, no. 7, pp. 37-42. 
Graham R.J., Englund R.L., Creating an Environment for Successful Projects, Jossey-Bass, San Francisco 1997.

Gray C.F., Larson E.W., Project Management - The managerial process, Irwin McGraw-Hill, New York 2003.

Hall E.T., Beyond culture, Anchor Press, Garden City 1976.

Handy Ch., Understanding organizations, Oxford University Press, New York 1983.

Hofstede G., Culture and organizations, "International Studies of Management and Organization" 1981, vol. 10(4), pp. 15-41.

Janosik E., Kutagowska E., Marzec S., Mazur-Kajta K., Wpływ fizycznych czynników środowiska pracy na obciq̨żenia praca monotypowa, "Zeszyty Naukowe Małopolskiej Wyższej Szkoły Ekonomicznej w Tarnowie" 2018, vol. 38, no. 2, pp. 121-137.

Jones R., Zarzqdzanie projektami. Sztuka przetrwania, MT Biznes, Warszawa 2007.

Kendra K., Taplin L.J., Project success: A cultural framework, “Project Management Journal” 2004, vol. 35(1), pp. 30-45.

Kerzner H., Applied Project Management. Best Practices on Implementation, John Wiley \& Sons, New York 2000.

Kivrak S., Arslan G., Tuncan M., Birgonul M.T., Impact of national culture on knowledge sharing in international construction projects, "Canadian Journal of Civil Engineering" 2014, vol. 41, pp. 642-649.

Levine H.A., Practical Project Management. Tips, Tactics, and Tools, John Wiley \& Sons, New York 2002.

Liu J., Meng F., Fellows R., An exploratory study of understanding project risk management from the perspective of national culture, "International Journal of Project Management" 2015, vol. 33, pp. 564-575.

Morrison J.M., Brown C.J., Smit E.V.D.M., The impact of organizational culture on project management in matrix organizations, "South African Journal of Business Management" 2008, vol. 39, no. 4, pp. 27-36.

Pinto J.K., Slevin D.P., Critical factors in successful project implementation, "IEEE Transactions on Engineering Management" 1987, no. 34, pp. 22-27.

Piwowar-Sulej K., Kultura organizacyjna i jej wpływ na działalność projektowq - studium przypadku, "Marketing i Rynek" 2014, no. 5, pp. 143-148.

Piwowar-Sulej K., Types of Organizational Culture in the context of Project Management Methodologies, [in:] Proceedings 35th International Business Information Management Association Conference (IBIMA), 1-2 April 2020, Seville [in print].

Piwowar-Sulej K., Zarzq̨dzanie ludźmi w organizacjach zorientowanych na projekty, Difin, Warszawa 2016.

Pritchard C., Zarzqdzanie ryzykiem w projektach. Teoria i praktyka, WIG Press, Warszawa 2001.

Shore B., Cross B.J., Exploring the role of national culture in the management of largescale international science projects, "International Journal of Project Management" 2005, vol. 23, pp. 55-64.

Siehl C., Martin J., The role of symbolic management: How can managers effectively transit organizational culture?, [in:] J. Hunt, D.M. Hosking, Ch.A. Schriesheim, R. Stewart (eds), Leaders and managers. International perspectives on managerial behavior and leadership, Elmsford, Pergamon, New York 1984, pp. 227-239.

Skalik J., Kulturowe uwarunkowania wzrostu i rozwoju organizacji gospodarczych, [in:] B. Mikuła (ed.), Historia i perspektywy nauk o zarzq̨dzaniu, Fundacja Uniwersytetu Ekonomicznego w Krakowie, Kraków 2012, pp. 123-130.

Standish Group, Chaos Report 2015, The Standish Group International, Inc., 2015, https://www.standis hgroup.com/sample_research_files/CHAOSReport2015-Final.pdf (accessed: 25.03.2020). 
Sudhakar G., Understanding the Meaning of Project Success, "Binus Business Review” 2016, vol. 7, pp. 163-169.

Wachowiak P., Gregorczyk S., Grucza B., Ogonek K., Kierowanie zespotem projektowym, Difin, Warszawa 2004.

Wiewióra A., Murphy G.D., Trigunarsyah B., Coffey V., Uncovering the Impact of Organizational Culture Types on the Willingness to Share Knowledge between Projects, [in:] Proceedings of the Conference: Kumamoto, Japan 2012, pp. 1-16.

Young T.L., Skuteczne zarządzanie projektami, Wydawnictwo Helion, Gliwice 2006.

Yu T., Wu N., A review of study on the competing values framework, "International Journal of Business and Management" 2009, vol. 4, no. 7, pp. 37-42.

\section{Abstract}

The purpose of the article is to present organizational culture as a project risk factor. The author addressed the literature approach to risk areas in projects. It was highlighted that since every organization has its own culture, a single project as a micro-organization has its own too. There is feedback between these cultures. Finally, the research results on the impact of culture on project success were presented. The article is of theoretical and pragmatic nature. The conducted literature review shows some implications for both management practitioners and theorists. The literature review also identifies features worth implementing in an organizational culture. While there is a general agreement that, e.g., culture promoting cooperation has a positive impact on project success, it is not possible to explicitly answer the question which type of culture (taking into account different typologies) remains the best (some of the above was changed in the main article).

Keywords: organizational culture, project management culture, project risk management 